\title{
The association between somatotype and nutritional status: a cross-sectional study among the adult Sabar males of Purulia, West Bengal, India
}

\author{
Kaustav Das ${ }^{1}$ (D) Koel Mukherjee ${ }^{2} \cdot$ Sayak Ganguli $^{3} \cdot$ Somosree Pal $^{4}$. \\ Subrata Sankar Bagchi ${ }^{4}$
}

Received: 16 July 2020 / Accepted: 14 April 2021 / Published online: 10 May 2021

(c) The Author(s). 2021

\begin{abstract}
Somatotype is the parameter used to determine the body composition, which is influenced by several factors and nutrition is the crucial one. This study aimed to determine somatotype and nutritional status as well as investigate the somatotype variations in relation to the age and nutritional status among the adult males of Sabar community living in Purulia district of West Bengal, India. The present cross-sectional study included 334 Sabar males aged between 18 to 60 years. Anthropometric measurements including height, weight, 2 breadths, 2 circumferences and 4 skinfolds were taken following standard protocol. Somatotype was determined following the Heath-Carter method and Body Mass Index (BMI) was used to access the level of nutrition. Descriptive statistics, Kruskal-Wallis H test, Pearson correlation, Spearman correlation and Chi-square test were performed to find out variation, correlation and association of the somatype components with age and nutritional categories. Prior ethical clearance had been obtained. As a result, the trend of undernutrition was gradually increasing with age and found highest among aged people (50-60 years) with an overall prevalence of $49.7 \%$. Eleven different somatotype subgroups were identified. The mean somatotype of the participants was 2.3-3.6-3.9 which indicates mesomorphectomorph body type. Kruskal-Wallis $H$ test revealed significant differences among somatotype components in different nutritional categories. Undernutrition was found highest among the mesomorphic ectomorph (62.7\%) type. Chi-square test

Kaustav Das

kaustavanthro@gmail.com

1 Department of Anthropology, Bangabasi College, Kolkata, West Bengal 700 009, India

2 Anthropological Survey of India, Andaman and Nicobar Regional Centre, Port Blair, India

3 Department of Biotechnology, St. Xavier's College (Autonomous), Kolkata, India

4 Department of Anthropology, University of Calcutta, Kolkata, India
\end{abstract}


stated significant association between somatotype categories and nutritional statuses (Chi-square $=283.160, p<0.01)$. This is the first reporting on the somatotype study among the Sabar community, where the dominant body type was found mesomorph-ectomorph. A highly significant correlation was found between somatotype and BMI. At the same time, this study expressed the need for immediate nutritional intervention.

Keywords Sabar · Somatotype · Endomorphy · Mesoporphy · Ectomorphy · Undernutrition

\section{Introduction}

Nowadays, millions of people throughout the world are suffering from different forms of malnutrition. An estimated 1.9 billion adults are overweight or obese while 462 million are underweight as recently as transpired in the WHO document during World Food Day 2019 (Organization WH 2020). Researchers in this field have identified malnutrition as a leading cause of death, disability, and ill-health (Organization WH 2013) as well as the most imminent risk factor for the disease burden in the Third World countries (Nemer et al. 2001).

In India, where the prevalence of malnutrition is considerably high (Shekar et al. 2017), many studies have been carried out to evaluate the nutritional status by using different anthropometric variables and most common of them is Body Mass Index (BMI) in relation to age, sex, occupation and socio-economic condition in different parts of India especially among the tribal groups (Bose et al. 2006; Mukherjee et al. 2015; Kshatriya and Acharya 2016; Sahani et al. 2018; Das et al. 2020). Researchers claim that the study of human health based on BMI is not always sufficient enough to generate a holistic insight of nutritional status as it is not regarded as an adequate alternative for somatotype (Genovese 2009). Sheldonian classification of somatotype is a method of description and quantification of the human body on three shape and composition scales: endomorphy (relative fatness characterised by the rounded shoulder, broad face, short neck, rounded physique), mesomorphy (relative musculoskeletal robustness with broad shoulder and chest, firm limbs), and ectomorphy (relative linearity as visibly slim physique, narrow and flat chest, long limbs) which was later modified by Heath and Carter (Sheldon et al. 1940; Heath and Carter 1967; Carter and Heath 1990). The latter form of classification known as the anthropometric somatotype method has proven to be more useful in various fields particularly in growth and ageing, body image, sports profiling etc. (Carter et al. 1983; Brukner and Bennell 2008; Hume and Ackland 2017).

Nutritional status of an individual is manifested through body size, shape and composition and over the last three decades, there have been a plethora of research works conducted in this field which have demonstrated the influence of somatotype on nutrition as well as on overall health status by focusing on the improvement of functional capacity (Leonardo Mendonça et al. 2012; Carrasco Alarcón et al. 2015; Penggalih et al. 2016; Hume and Ackland 2017). Nevertheless, studies have also been conducted to find out the association of somatotype with arterial hypertension 
(Koleva et al. 2002), abdominal adiposity (Williams et al. 2000; Ramos-Jiménez et al. 2019), blood pressure (Kalichman et al. 2004), type 2 diabetes (Baltadjiev 2013; Urrutia-García et al. 2015) etc. In India, the studies on somatotype are mostly on population variations in terms of age and sex variation - mainly conducted among children, adolescents and women (Gaur and Singh 1997; Gaur et al. 1999; Gakhar and Malik 2002; Dkhar 2005; Bhasin and Jain 2007; Singh 2011; Srivastava et al. 2012; Chandel and Malik 2012; Roy and Kundu Chowdhury 2013; Longkumer 2014; Kaur and Malik 2016; Kaur et al. 2018; Chandel et al. 2018; Mallick et al. 2018; Shimrah et al. 2020). However, such studies especially in adult tribal populations, are very few and far between (Ghosh and Malik 2010).

India as a country is unique in its cultural milieu as it is the home to more than 2 thousand ethnic groups including 705 tribal communities (Census of India 2011). Sabar (AKA: Savar) is one of them. They prefer to live in small groups comprising of 10 to 15 families in isolation away from neighbouring communities. In the state of West Bengal, they are mostly distributed in the remote areas of the districts of Purulia, Bankura, Jhargram, Paschim Medinipur etc. Traditionally they were foragers and living in the forest but after the implementation of various acts of forest protection from time to time in India, they were gradually forced to leave their traditional habitat and settle in areas close to the jungle. Historically they lack the necessary skill of agriculture or any other mode of subsistence suitable for a sedentary lifestyle. This factor along with their poor acceptance of formal education necessary for a descent sedentary life, made them more marginalized and forced them to live in abject poverty. Most of them now do not have an option to earn their livelihood except by working as a wage labourer in the field of agriculture, road construction, mines, tea gardens etc. (Das et al. 2019), requiring strenuous physical activities that affect their body composition. Thus the severance from their traditional livelihood and the uncertain, as well as strenuous activities as wage labourers are wreaking havoc in their socio-economic life and there are various reports (Guha 2016; Press Trust of India 2018; Nandi 2019) of starvations among the Sabar people of West Bengal. This background makes it more imperative to study the nutritional status of Sabar males in terms of anthropometric somatotype.

Till date, no such study using anthropometric somatotype has been reported among the Sabar males as the scholars have mostly concentrated in studies based on BMI (Bose et al. 2006; Dhargupta et al. 2009; Chakrabarty and Bharati 2012; Ghosh et al. 2018). To the best of our knowledge, the present study is the first attempt to: determine somatotype and nutritional status as well as investigate the somatotype variations in relation to the age and nutritional status among the adult males of Sabar community living in Purulia district of West Bengal.

\section{Methods}

In this cross-sectional study, 334 Sabar males aged between 18 to 60 years have been examined from the Purulia district of West Bengal. Purulia is the westernmost district of West Bengal and around $250 \mathrm{~km}$ away from the state capital, Kolkata. Data were collected from 15 villages under four administrative blocks, namely, 
Purulia-I (village- Akarbad), Manbazar-I (village- Kuda, Punru, Bamni, Jonarah, Jabla, Kasidih and Makarkendi), Puncha (village- Damodarpur, Babuijor, Balakdih, Bankanali and Bengthupi) and Bandwan (village- Amjharna and Popo) block. All the participants were selected at random based on their availability during the study. They were found physically and mentally normal and did not suffer from any apparent illness at the time of the study. The study protocol was approved by the Research and Ethics committee of Bangabasi College, University of Calcutta, West Bengal (No. 002/2017). Prior permission has been obtained from the local administration. Before the commencement of the study, the participants were informed of and explained the objectives of the study and their consent were taken.

For the assessment of somatotype and nutritional status, 10 anthropometric measurements namely height $(\mathrm{cm})$; weight $(\mathrm{kg})$; biepicondylar breadth $(\mathrm{cm})$ of humerus and femur; skinfolds $(\mathrm{mm})$ at triceps, sub-scapula, supra-spinale and calf; circumferences $(\mathrm{cm})$ at mid-upper-arm when the arm is flexed and mid-calf have been taken from all the subjects following standardised protocols established by the International Society for the Advancement of Kinanthropometry (ISAK 2011). Martin's anthropometer rod was used to determine height; digital weighing machine (OMRON HN 289) for measuring weight; Skinfold calliper (Slim Guide) for skinfolds and calibrated non-elastic measuring tape (Gulick Anthropometric Tape) were used for measuring circumferences. All the measurements were taken on the right side of the subjects. Technical errors of measurements have been found within the acceptable limit (Ulijaszek and Kerr 1999). BMI was calculated following the equation: BMI $\left(\mathrm{kg} / \mathrm{m}^{2}\right)=$ Weight $(\mathrm{kg}) /$ Height $\left(\mathrm{m}^{2}\right)$. To determine nutritional status, WHO cut off was used (Organization WH 1995) and participants were grouped into three nutritional categories: undernutrition $\left(<18.5 \mathrm{~kg} / \mathrm{m}^{2}\right)$, normal $(18.5-24.9$ $\left.\mathrm{kg} / \mathrm{m}^{2}\right)$ and overweight $\left(\geq 25.0 \mathrm{~kg} / \mathrm{m}^{2}\right)$. Somatotype analysis and classification were done by following the Heath-Carter method (Heath and Carter 1967; Carter and Heath 1990; Carter 2002). The following equations were used (Carter 2002):

$$
\text { Endomorphy }=-0.7182+0.1451(\mathrm{X})-0.00068\left(\mathrm{X}^{2}\right)+0.0000014\left(\mathrm{X}^{3}\right)
$$

Where $X=$ (sum of triceps, sub-scapular and supra-spinale skinfolds) multiplied by $(170.18$ / height in $\mathrm{cm})$.

$$
\begin{aligned}
\text { Mesomorphy }= & (0.858 \times \text { humerus breadth })+(0.601 \times \text { femur breadth }) \\
& +(0.188 \times \text { corrected arm girth }) \\
& +(0.161 \times \text { corrected calf girth })-(0.131 \times \text { height }) \\
& +4.5 \text { Corrected arm girth }: \operatorname{arm} \text { girth }(\mathrm{cm}) \\
& -(\text { triceps skinfold } / 10)(\mathrm{mm}) ; \text { Corrected calf girth }: \text { calf girth }(\mathrm{cm}) \\
& -(\text { calf skinfold } / 10)(\mathrm{mm})
\end{aligned}
$$

\section{Ectomorphy}


If $\mathrm{HWR} \geq 40.75$, Ectomorphy $=(0.732 \times \mathrm{HWR})-28.58$

If HWR $<40.75$ and $>38.25$, Ectomorphy $=(0.463 \times$ HWR $)-17.63$

If $\mathrm{HWR} \leq 38.25$, Ectomorphy $=0.1$

HWR : height $(\mathrm{cm}) /$ weight $^{1 / 3}(\mathrm{~kg})$

Plotting somatotypes on 2-D somatochart:

$$
X \text {-coordinate }=\text { Ectomorphy-Endomorphy }
$$

$\boldsymbol{Y}$-coordinate $=2 \mathrm{x}$ Mesomorphy $-($ Endomorphy + Ectomorphy $)$

The data were analyzed using SPSS version 16.0 (SPSS Inc., Chicago, IL, USA). The significance level of 0.05 and 0.01 was set for analysis. Participants were categorized into four age groups: Group I (18-27 years), Group II (28-39 years), Group III (40-49 years) and Group IV (50-60 years). Descriptive statistics were used to find out mean, standard deviation (SD), minimum and maximum values for all the anthropometric variables, somatotype components, BMI and age. Normality test (including both the Kolmogorov-Smirnov test and the ShapiroWilk's test) for somatotype components of the subjects have been performed. Kruskal-Wallis $\mathrm{H}$ test was applied to find out the variation of somatotype components among different age groups as well as in different nutritional categories. Pearson's correlation was used to find out the correlation between somatotype components (continuous values) and nutritional categories, and Spearman's correlation analysis for somatotype categories and nutritional categories. Association in somatotype categories among different nutritional categories was analysed using the Chi-square test.

\section{Results}

Descriptive statistics for all the anthropometric variables, somatotype components and age have been presented in Table 1 . The mean $( \pm \mathrm{SD})$ age of the participants was $38.8( \pm 12.9)$ years with a range of 18 to 60 years. In the case of BMI, the mean value was $18.8( \pm 2.2) \mathrm{kg} / \mathrm{m}^{2}$. The overall mean of somatotype components viz. endomorphy, mesomorphy and ectomorphy was $2.3( \pm 0.9)-3.6( \pm 1.1)-3.9( \pm$ 1.3). This overall result revealed that the participants have mesomorph-ectomorph body type. Somatotype values of all participants were plotted in a somatochart following mean values of $\mathrm{X}(1.6 \pm 2.0)$ and $\mathrm{Y}(1.1 \pm 2.9)$ coordinates and presented in Figs. 1 and 2.

Age group-wise distribution of the population based on nutritional status showed that almost half (49.7\%) of the studied population was undernourished (Table 2). Prevalence of undernourished participants was found to be increased with age. Interestingly, the frequency of normal individuals was decreased simultaneously. Very nominal frequency of overweight participants was observed $(2.1 \%)$.

Variation of somatotype components among different age groups of the studied population has been presented in Table 3. Kruskal-Wallis $\mathrm{H}$ test showed no 
Table 1 Descriptive statistics of the age and anthropometric variables among the studied population

\begin{tabular}{lllll}
\hline Anthropometric variables & Mean & SD & Minimum & Maximum \\
\hline Age (years) & 38.8 & 12.9 & 18.0 & 60.0 \\
Height (cm) & 162.1 & 5.4 & 140.5 & 176.0 \\
Weight (kg) & 49.5 & 6.5 & 35.0 & 77.1 \\
Skinfolds & & & & \\
$\quad$ Biceps (mm) & 3.0 & 1.1 & 1.0 & 14.0 \\
Triceps (mm) & 5.9 & 2.4 & 2.0 & 19.0 \\
Sub-scapular (mm) & 8.8 & 3.5 & 3.0 & 30.0 \\
Supra-spinale (mm) & 7.4 & 3.0 & 2.0 & 20.0 \\
$\quad$ Medial calf (mm) & 5.3 & 2.2 & 2.0 & 18.0 \\
Circumferences & & & & \\
$\quad$ Arm flexed (cm) & 26.3 & 2.3 & 20.6 & 34.0 \\
Calf (cm) & 29.7 & 2.6 & 21.7 & 38.9 \\
Breadth & & & & \\
$\quad$ Humerus (cm) & 6.4 & 0.3 & 5.4 & 8.4 \\
$\quad$ Femur (cm) & 8.7 & 0.6 & 3.2 & 10.0 \\
Somatotype components & & & & \\
$\quad$ Endomorphy & 2.3 & 0.9 & 0.7 & 6.6 \\
$\quad$ Mesomorphy & 3.6 & 1.1 & -0.3 & 6.5 \\
Ectomorphy & 3.9 & 1.3 & 0.1 & 8.2 \\
Somatochart coordinates & & & & 7.0 \\
X Coordinates & 1.6 & 2.0 & -6.5 & 8.1 \\
Y Coordinates & 1.1 & 2.9 & -10.0 & \\
BMI (kg/m $\left.{ }^{2}\right)$ & 18.8 & 2.2 & 13.3 & 30.7 \\
\hline
\end{tabular}

statistically significant differences for somatotype components of endomorphy (Chisquare $=1.718, p>0.05$ ) and mesomorphy (Chi-square $=7.692, p>0.05$ ), but there was a statistically significant difference in ectomorphy component (Chi-square = 10.792, $p<0.05$ ) between different age groups with a mean rank value of 143.7 for Group I, 161.4 for Group II, 176.4 for Group III and 190.2 for Group IV.

On the other hand, in Table 4, Kruskal-Wallis $\mathrm{H}$ test revealed significant differences for all somatotype components of endomorphy (Chi-square $=96.203, p<$ $0.01)$, mesomorphy (Chi-square $=139.784, p<0.01)$ and ectomorphy (Chi-square $=$ 228.281, $p<0.01$ ) among three nutritional categories.

As a result of the research, 11 somatotype categories were identified and presented in Table 5. It has been revealed that mesomorphic ectomorph (34.7\%) type has the highest frequency of occurrence followed by mesomorph-ectomorph (14.18\%), ectomorphic mesomorph (12.6\%) and balanced ectomorph (11.7\%) among the studied population. Under the nutritional category of undernutrition, mesomorphic ectomorph was found to be the highest in frequency (62.7\%). Again in the normal category of BMI, Mesomorph-ectomorph has exhibited the highest frequency (22.4\%). Furthermore, Endomorphic mesomorph (42.9\%) was found to be highest in frequency in the overweight category of BMI. Chi-square test has 


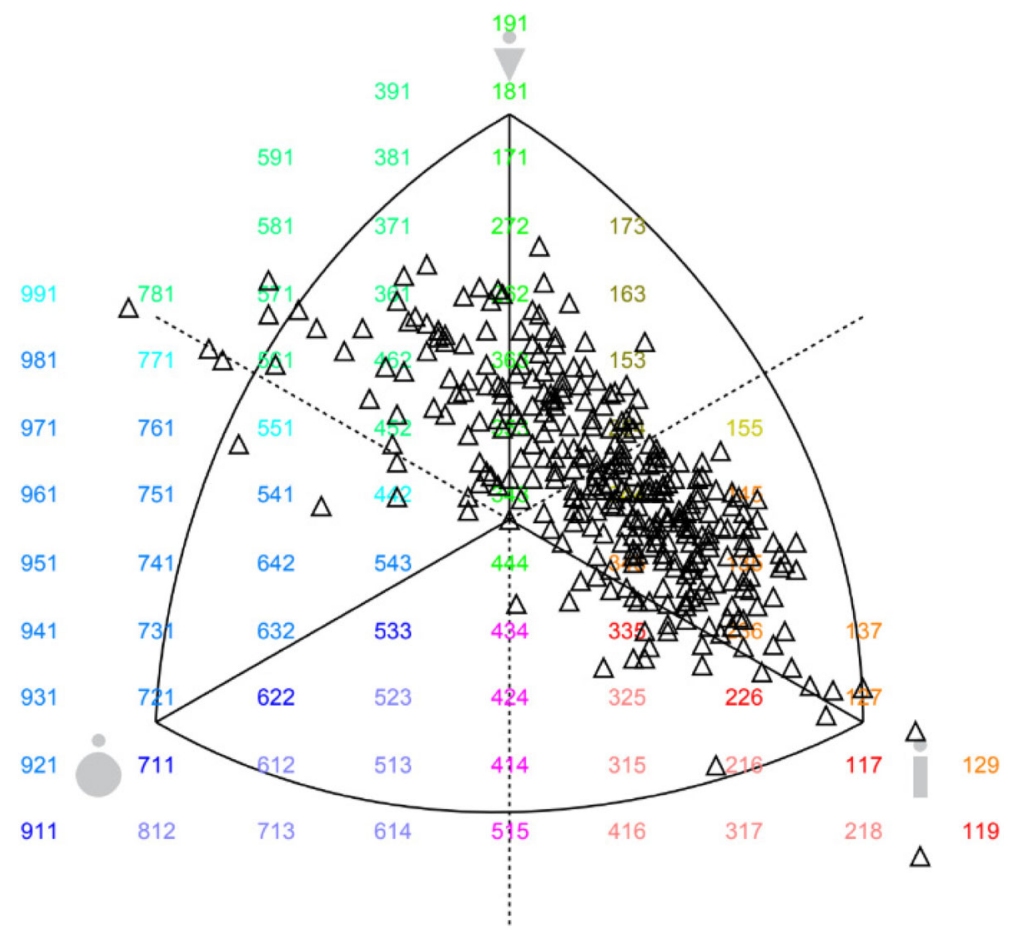

\section{$\triangle:$ Sabar Males}

Fig. 1 Somatochart providing an overall representation of the studied population

revealed a statistically significant association between somatotype categories and nutritional status based on BMI (Chi-square $=283.160, p<0.01)$.

The correlation between somatotype and BMI of the studied population has been presented in Table 6. Pearson's correlation performed between absolute BMI values with somatotype components and somatochart coordinates. Results revealed significant positive correlation for endomorphy $(r=0.745)$, mesomorphy $(r=0.734)$ and Y coordinate $(r=0.750)$ and negative correlation for ectomorphy $(r=-0.943)$ and X coordinate $(r=-0.939)$ with BMI. In addition to that, Spearman Rho of -0.745 indicated a statistically significant $(p<0.01)$ negative correlation in the ranking of 11 somatotype categories and nutritional categories of undernutrition, normal and overweight.

\section{Discussion}

The present study conducted among 334 adults Sabar males of Purulia district of West Bengal, revealed comparatively lower mean BMI value $\left(18.8 \pm 2.2 \mathrm{~kg} / \mathrm{m}^{2}\right)$ and consequently higher frequency of undernutrition $(49.7 \%)$ among the participants. It has also been observed that the BMI of the participants decreased with age and maximum undernourishment was found among the aged people of Group 


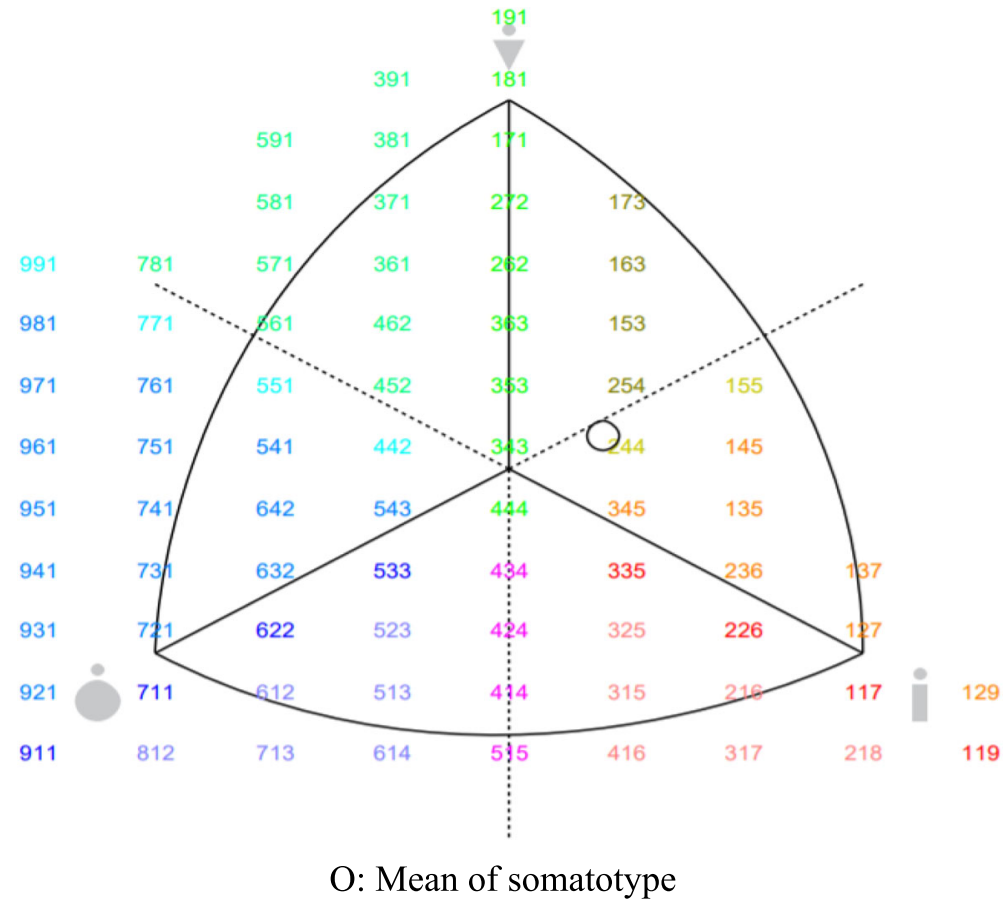

Fig. 2 Somatochart representing the mean of somatotype of the studied population

IV (50-60 years). In the case of somatotype components, ectomorphy has been changed significantly $(p<0.05)$ among different age groups which indicated the changes in body composition with ageing. Generally, with ageing fat mass increases but lean mass and bone mineral density decrease and these changes in body composition usually associated with weight fluctuations (St-Onge and Gallagher 2010). Again the mean rank values of endomorphy and mesomorphy components were found to be decreased with ageing though the result could not find statistically significant values. The mean somatotype of the community was 2.3-3.6-3.9 which expressed mesomorph-ectomorph body type. Similar findings have also been reported from earlier studies on the Meitei boys of Manipur (2.5-3.2-3.7) (Singh 2011), Ao Naga children of Nagaland (1.8-3.9-3.8) (Longkumer 2016) and Warli tribal community of Dadra and Nagar Haveli (2.8-3.6-3.5) (Chandel et al. 2018). Mesomorphic ectomorph type was also reported from the study on Meiteis of Manipur by Gaur et al. (1999) and Oraons of West Bengal by Roy and Kundu Chowdhury (2013). On the other hand, ectomorphic mesomorph type was found dominant among the Santal males (1.9-4.8-3.9) of West Bengal (Ghosh and Malik 2010), Kshatriya (2.2-4.6-3.9) and Kurmi (2.3-6.5-3.4) males of Uttar Pradesh (Chandel and Malik 2012). Furthermore, the significant difference of somatotype components among the three nutritional categories was observed. Here, it is clear that endomorphy and mesomorphy have been increased from undernutrition to overweight but ectomorphy showed the reverse trend. In this study, both of the 
Table 2 Age group wise distribution of studied population based on nutritional status

\begin{tabular}{lllll}
\hline $\begin{array}{l}\text { Age Group } \\
\text { (years) }\end{array}$ & \multicolumn{2}{l}{ Nutritional Status } & \multicolumn{2}{l}{ Total } \\
\cline { 2 - 4 } & \multicolumn{2}{l}{ Undernutrition } & Normal & \multicolumn{2}{l}{ Overweight } \\
\hline Group I: $18-27$ & $33(9.9)$ & $51(15.3)$ & $2(0.6)$ & $86(25.7)$ \\
Group II: 28-39 & $40(12.0)$ & $44(13.2)$ & $2(0.6)$ & $86(25.7)$ \\
Group III: $40-$ & $40(12.0)$ & $39(11.7)$ & $1(0.3)$ & $80(24.0)$ \\
49 & & & & \\
Group IV: $50-$ & $53(15.9)$ & $27(8.1)$ & $2(0.6)$ & $82(24.6)$ \\
60 & & & & \\
Total & $166(49.7)$ & 161 & $7(2.1)$ & 334 \\
& & $(48.2)$ & & $(100)$ \\
\hline
\end{tabular}

Percentages are presented in parentheses

participants who were classified as undernourished and normal showed a comparatively higher incidence of the mesomorphic ectomorph and mesomorph-ectomorph body type, respectively. Overall, the Sabar male participants have exhibited the highest incidence of the mesomorphic ectomorph (34.7\%) which means linear as well as muscular body type, since the participants of this study were mostly engaged in daily wage work which demands lots of muscular activities in their day to day survival. This could be the crucial factor behind the occurrence of predominantly mesomorphic component and the findings were in good agreement with earlier studies in this field (Singal and Sidhu 1984; Singal et al. 1988; Vyse 1997; Ghosh and Malik 2010; Roy and Kundu Chowdhury 2013).

Apart from that, the presence of their prevalent linearity may also be a result of inadequate calorie intake. Sabar, traditionally a gathering and hunting tribe derived more than half of their subsistence energy from animal foods and that because wild plant foods have relatively low carbohydrate content and the level of protein intake became increased at the expense of carbohydrate. During this fieldwork, it has been observed that the predominant presence of dietary diversity included a wide variety of wild and uncultivated plant foods such as leafy vegetables, roots, starchy tubers, seeds, fruits and nuts were gathered from forest areas. Sabars are not free to determine their diets; rather, it was their predetermined biological requirements for particular nutrients that shaped their physique. Presence of ectomorphy and mesomorphy as somatotype variants has indicated that consumption of animal matter to satisfy requirements for protein and other essential micronutrients would free up space in the gut for carbohydrate-rich plant food, as they consume a mixed diet of

Table 3 Variation of somatotype components of the studied population among different age groups (Kruskal Wallis $\mathrm{H}$ test)

\begin{tabular}{|c|c|c|c|c|c|c|}
\hline \multirow{2}{*}{$\begin{array}{l}\text { Somatotype } \\
\text { components }\end{array}$} & \multicolumn{4}{|c|}{ Age Group (years) } & \multirow{2}{*}{$\begin{array}{l}\text { Chi- } \\
\text { square }\end{array}$} & \multirow[t]{2}{*}{ Sig. } \\
\hline & $\begin{array}{l}\text { Group I } \\
18-27 \\
(N= \\
86)\end{array}$ & $\begin{array}{l}\text { Group } \\
\text { II 28-39 } \\
(N=86)\end{array}$ & $\begin{array}{l}\text { Group } \\
\text { III } 40- \\
49(N= \\
80)\end{array}$ & $\begin{array}{l}\text { Group } \\
\text { IV } 50- \\
60(N= \\
82)\end{array}$ & & \\
\hline Endomorphy & 177.9 & 167.4 & 158.5 & 165.5 & 1.718 & .633 \\
\hline Mesomorphy & 191.5 & 164.3 & 153.2 & 159.6 & 7.692 & .053 \\
\hline Ectomorphy & 143.7 & 161.4 & 176.4 & 190.2 & 10.792 & .013 \\
\hline
\end{tabular}


Table 4 Variation of somatotype components of the studied population among different nutritional categories (Kruskal Wallis H test)

\begin{tabular}{llllll}
\hline $\begin{array}{l}\text { Somatotype } \\
\text { components }\end{array}$ & \multicolumn{2}{l}{ Nutritional Categories } & & $\begin{array}{l}\text { Chi- } \\
\text { square }\end{array}$ & Sig. \\
\cline { 2 - 5 } & Undernutrition & Normal & Overweight & & \\
\hline Endomorphy & 118.2 & 211.3 & 329.9 & 96.203 & .000 \\
Mesomorphy & 106.1 & 224.2 & 319.2 & 139.784 & .000 \\
Ectomorphy & 246.8 & 92.8 & 4.3 & 228.281 & .000 \\
\hline
\end{tabular}

animal (rat, snake, wild pig, rabbit etc) and plant foods, it gives the apparent limitations of human digestive physiology to secure adequate daily energy from protein source alone (Milton 2000). Here it should be noted that wild game meats are lower in saturated fat and provide moderate to high protein as well as higher shares of monounsaturated and polyunsaturated fatty acids when compared with meats from domesticated animals (Crittenden and Schnorr 2017).

On the other hand, few studies suggest that dietary pattern can alter microbial composition of an individual which have broad implications for human health (Walker et al. 2011; Wu et al. 2011; David et al. 2014). Microbes present in the human gut contribute to the health of an individual by not only synthesizing the vitamins and other essential nutrients but also generating important metabolic byproducts from undigested dietary components left by the small intestine (Bäckhed et al. 2005; Singh et al. 2017).

Somatotype variation and nutritional assessment by BMI of the studied population in transition suggested that introducing a diet dominated by domesticated

Table 5 Distribution of somatotype categories among different nutritional status

Percentages are presented in parentheses; $\mathrm{df}=20$

\begin{tabular}{|c|c|c|c|c|c|c|}
\hline \multirow{2}{*}{$\begin{array}{l}\text { Somatotype } \\
\text { categories }\end{array}$} & \multicolumn{3}{|c|}{ Nutritional Status } & \multirow[t]{2}{*}{ Total } & \multirow{2}{*}{$\begin{array}{l}\text { Chi- } \\
\text { Square }\end{array}$} & \multirow[t]{2}{*}{ Sig. } \\
\hline & Undernutrition & Normal & Overweight & & & \\
\hline Central & $0(0.0)$ & $7(4.3)$ & $0(0.0)$ & $7(2.1)$ & 283.160 & .000 \\
\hline $\begin{array}{l}\text { Mesomorphic } \\
\text { endomorph }\end{array}$ & $0(0.0)$ & $2(1.2)$ & $2(28.6)$ & $4(1.2)$ & & \\
\hline $\begin{array}{l}\text { Mesomorph- } \\
\text { endomorph }\end{array}$ & $0(0.0)$ & $6(3.7)$ & $2(28.6)$ & $8(2.4)$ & & \\
\hline $\begin{array}{l}\text { Endomorphic } \\
\text { mesomorph }\end{array}$ & $0(0.0)$ & $\begin{array}{l}28 \\
(17.4)\end{array}$ & $3(42.9)$ & $\begin{array}{l}31 \\
(9.3)\end{array}$ & & \\
\hline $\begin{array}{l}\text { Balanced } \\
\text { mesomorph }\end{array}$ & $0(0.0)$ & $\begin{array}{l}30 \\
(18.6)\end{array}$ & $0(0.0)$ & $\begin{array}{l}30 \\
(9.0)\end{array}$ & & \\
\hline $\begin{array}{l}\text { Ectomorphic } \\
\text { mesomorph }\end{array}$ & $8(4.8)$ & $\begin{array}{l}34 \\
(21.1)\end{array}$ & $0(0.0)$ & $\begin{array}{l}42 \\
(12.6)\end{array}$ & & \\
\hline $\begin{array}{l}\text { Mesomorph- } \\
\text { ectomorph }\end{array}$ & $12(7.2)$ & $\begin{array}{l}36 \\
(22.4)\end{array}$ & $0(0.0)$ & $\begin{array}{l}48 \\
(14.8)\end{array}$ & & \\
\hline $\begin{array}{l}\text { Mesomorphic } \\
\text { ectomorph }\end{array}$ & $104(62.7)$ & $\begin{array}{l}12 \\
(7.5)\end{array}$ & $0(0.0)$ & $\begin{array}{l}116 \\
(34.7)\end{array}$ & & \\
\hline $\begin{array}{l}\text { Balanced } \\
\text { ectomorph }\end{array}$ & $35(21.1)$ & $4(2.5)$ & $0(0.0)$ & $\begin{array}{l}39 \\
(11.7)\end{array}$ & & \\
\hline $\begin{array}{l}\text { Endomorphic } \\
\text { ectomorph }\end{array}$ & $7(4.2)$ & $1(0.6)$ & $0(0.0)$ & $8(2.4)$ & & \\
\hline $\begin{array}{l}\text { Endomorph- } \\
\text { ectomorph }\end{array}$ & $0(0.0)$ & $1(0.6)$ & $0(0.0)$ & $1(0.3)$ & & \\
\hline Total & $166(49.7)$ & $\begin{array}{l}161 \\
(48.2)\end{array}$ & $7(2.1)$ & $\begin{array}{l}334 \\
(100.0)\end{array}$ & & \\
\hline
\end{tabular}


Table 6 Correlations between BMI and somatotype components

\begin{tabular}{lll}
\hline $\begin{array}{ll}\text { A: Pearson's correlation } \\
\text { BMI-Somatotype Components }\end{array}$ & $\begin{array}{l}\text { B: Spearman's correlation } \\
\text { BMI-Somatotype Categories }\end{array}$ \\
\hline Endomorphy & 0.745 & -0.745 \\
Mesomorphy & 0.734 & \\
Ectomorphy & -0.943 & \\
X coordinate & -0.939 & \\
Y coordinate & 0.750 & \\
\hline
\end{tabular}

In all cases $p<0.001$

cultigens and high levels of alcohol consumption has negative health effects as observed in presence of overweight $(2.1 \%)$. Findings from different studies have provided convincing evidence of the nutrition and health benefits of dietary diversity which was enhanced by wild food plants (Basu et al. 1987; Onyango et al. 1998; Frison et al. 2006). In the present context, the locally available food plants required correct taxonomic identification and bio-chemical analysis, failing which results only depending on phenotypic expression for assessing health conditions can not be interpreted correctly and fully.

Recent works on intestinal physiology demonstrated statistically significant differences in gut bacterial community diversity associated with the nutritional status of an individual (Gao et al. 2018; Wan et al. 2020). Studies have shown that diet widely influences the gut microbiome and partially impacted human ability to extract and store calories as fat from food (Turnbaugh et al. 2006; Menni et al. 2017). In this context, a recent study of present authors on the gut microbial dataset of Savar tribal community of West Bengal showed that Savar gut microbial profile represents an abundance of unadulterated microbes constituted by Ruminococcaceae (15\%), Succinovibrio (12\%) and Bacteroides (31\%) (Ganguli et al. 2019). Another study conducted by Menni et al. (2017) showed the possibility that Ruminococcus may be functionally linked to the lean phenotype, whereas, Gao et al. (2018) in his study indicated a significant association between bacterial communities and underweight; therefore, the gut microbial composition may play a role in the regulation of human body composition as well as body weight. All the above-mentioned studies suggested that there may be an inherent association of gut microbiome with the dietary pattern which can have an impact on human nutritional status and such data subsequently, has the potential of tremendous use to policy implementations as well as for future potential research work on the health of indigenous people in transition.

\section{Conclusion}

This study reveals a high prevalence of undernutrition among the participants, particularly among the aged people, compared to younger participants which require immediate nutritional intervention. BMI values were found gradually decreasing with age. This is the first reporting on the somatotype study among the Sabar community, where the dominant body type was mesomorph-ectomorph. Following the Heath-Carter method, 11 body types were identified where mesomorphy and 
ectomorphy components were found dominant. Existing correlation between somatotype elements and BMI presented highly significant values. However, this study needs to be validated in different communities with large sample size focusing on the nutritional level of the population. In this context, the present study also identifies the scarcity of data on local level dietary diversity and associated indigenous knowledge which are getting petered out with time away due to the immense pressure to change the traditional lifestyle relating to food choice and preference among the erstwhile foraging tribal groups like the Sabars. The efforts to implement the nutritional programme from government and non-government agencies would not bring the desired nutritional level unless these agencies focus at micro-level implementation to bridge the gaps in the nutritional level. Anthropological approaches and methods can be used most effectively for micro-level planning in the making of strategies considering ecological, regional, cultural and psychological value system associated with diversified food habits leading to the formulation of more realistic and effective nutrition and health improvement programmes.

Acknowledgements The authors gratefully acknowledge all the participants for their kind cooperation and help during data collection. Special thanks to the non-government organization Paschim Banga Kheria Sabar Kalyan Samity for their logistic support during fieldwork.

Authors' contributions $\mathrm{KD}, \mathrm{KM}$ and SSB designed the study; KD, KM and SP conducted the field and collected the data; KD and KM performed the statistical analysis and prepared the first draft of the manuscript; SG and SSB critically revised the manuscript and prepared the final draft. The author(s) read and approved the final manuscript.

Funding This research received no external funding.

Availability of data and materials The dataset of this study could be accessed from the corresponding author on reasonable request.

\section{Declarations}

Ethics approval and consent to participate The study protocol was approved by the Research and Ethics committee of Bangabasi College, University of Calcutta, West Bengal (No. 002/2017). Before the commencement of the study, the participants were informed and explained the objectives of the study and their consent were taken.

Consent for publication We accept the copyright regulation of your journal and authorize your journal to publish our paper, if possible.

Competing interests The authors declare no conflict of interest.

Open Access This article is licensed under a Creative Commons Attribution 4.0 International License, which permits use, sharing, adaptation, distribution and reproduction in any medium or format, as long as you give appropriate credit to the original author(s) and the source, provide a link to the Creative Commons licence, and indicate if changes were made. The images or other third party material in this article are included in the article's Creative Commons licence, unless indicated otherwise in a credit line to the material. If material is not included in the article's Creative Commons licence and your intended use is not permitted by statutory regulation or exceeds the permitted use, you will need to obtain permission directly from the copyright holder. To view a copy of this licence, visit http:// creativecommons.org/licenses/by/4.0/. 


\section{References}

Bäckhed, F., R.E. Ley, J.L. Sonnenburg, D.A. Peterson, and J.I. Gordon. 2005. Host-bacterial mutualism in the human intestine. Science 307 (5717): 1915-1920. https://doi.org/10.1126/science.1104816.

Baltadjiev, A.G. 2013. Somatotype characteristics of female patients with type 2 diabetes mellitus. Folia Medica (Plovdiv) 55 (1): 64-69. https://doi.org/10.2478/folmed-2013-0007.

Basu, A., S. Mukhopadhyay, P.P. Majumdar, S.K. Roy, B. Mukhopadhyay, P. Bharati, et al. 1987. Food practices in contrasting populations: An anthropological study of Sherpas, Lepchas, Oraons and Mahishyas of West Bengal. Social Science Information 26 (4): 847-868. https://doi.org/10.1177/053901887026004007.

Bhasin, M.K., and S. Jain. 2007. Biology of the tribal groups of Rajasthan, India: Age changes in somatotype. The Anthropologist 9 (4): 257-265.

Bose, K., F. Chakraborty, S. Bisai, A. Khatun, and H. Bauri. 2006. Body mass index and nutritional status of adult Savar tribals of Keonjhar District, Orissa, India. Asia Pacific Journal of Public Health 18 (3): 3-7. https://doi.org/10.1177/10105395060180030201.

Brukner, P.D., and K.L. Bennell. 2008. Stress fractures: Their causes and principles of treatment. In Baxter's the foot and ankle in sport, ed. D.A. Porter and L.C. Schon, 2nd ed., 45-72. Philadelphia: Mosby. https://doi.org/10.1016/B978-0-323-02358-0.X1000-7.

Carrasco Alarcón, V., C. Martínez Salazar, C. Álvarez Lepín, C. Jorquera Aguilera, and N. Aguilar Farías. 2015. Variation on somatotype and waist circumference in a sample of university students between years 2012 and 2014 in the Temuco, Chile. Nutricion Hospitalaria 32 (1): 373-378. https://doi.org/10.3305/ nh.2015.32.1.9022.

Carter, J.E. 2002. The Heath-Carter anthropometric somatotype-instruction manual. San Deigo: s.n.

Carter, J.E.L., and B.H. Heath. 1990. Somatotyping- development and applications. Cambridge: Cambridge University Press, UK.

Carter, J.E.L., W.D. Ross, W. Duquet, and S.P. Aubry. 1983. Advances in somatotype methodology and analysis. Yearbook of Physical Anthropology 26 (S1): 193-213. https://doi.org/10.1002/ajpa.1330260509.

Census of India. 2011. Office of the Registrar General and Census Commission. New Delhi: Government of India.

Chakrabarty, S., and P. Bharati. 2012. Household economy and nutritional status among the Shabar tribe living in a protected forest area of Orissa, India. Human Biology Review 1 (1): 22-37.

Chandel, S., and S.L. Malik. 2012. Anthropometric somatotype of Kshatriya and Kurmi of Uttar Pradesh: Population and gender differences. Human Biology Review 1: 1-15.

Chandel, S., A. Rhetso, S.L. Malik, and M. Kulshreshtha. 2018. The association between body physique and physical fitness: A cross-sectional study among a tribal community of Dadra and Nagar Haveli, India. International Journal of Applied Exercise Physiology 7 (1): 11-20.

Crittenden, A.N., and S.L. Schnorr. 2017. Current views on hunter-gatherer nutrition and the evolution of the human diet. American Journal of Physical Anthropology 162 (Suppl 63): 84-109.

Das, K., K. Mukherjee, M. Chanak, S. Pal, S. Ganguli, S.S. Bagchi, and K. Bose. 2019. Co-existence of high levels of undernutrition and hypertension among Sabar males of Purulia, West Bengal, India: A paradox. International Journal of Advancement in Life Sciences Research 2 (4): 38-47.

Das, K., K. Mukherjee, M. Chanak, S. Pal, S. Ganguli, S.S. Bagchi, and K. Bose. 2020. Age trends in under-nutrition among Sabar males of Purulia, West Bengal, India. Journal of Human Ecology 70 (1-3): 110-117.

David, L.A., C.F. Maurice, R.N. Carmody, D.B. Gootenberg, J.E. Button, B.E. Wolfe, A.V. Ling, A.S. Devlin, Y. Varma, M.A. Fischbach, S.B. Biddinger, R.J. Dutton, and P.J. Turnbaugh. 2014. Diet rapidly and reproducibly alters the human gut microbiome. Nature 505 (7484): 559-563. https://doi.org/10.1038/na ture 12820 .

Dhargupta, A., A. Goswami, M. Sen, and D. Mazumder. 2009. Study on the effect of socio-economic parameters on health status of the Toto, Santal, Sabar and Lodha tribes of West Bengal, India. Studies of Tribes and Tribals 7 (1): 31-38.

Dkhar, J.W. 2005. Somatotypes among the Pnar boys of Meghalaya. Bulletin of Anthropology 33: 85-92.

Frison, E.A., I.F. Smith, T. Johns, J. Cherfas, and P.B. Eyzaguirre. 2006. Agricultural biodiversity, nutrition, and health: Making a difference to hunger and nutrition in the developing world. Food and Nutrition Bulletin 27 (2): 167-179. https://doi.org/10.1177/156482650602700208.

Gakhar, I., and S.L. Malik. 2002. Age changes and sex differences in somatotypes among Jats of Delhi. The Anthropologist 4 (Special Issue): 115-125.

Ganguli, S., S. Pal, K. Das, R. Banerjee, and S.S. Bagchi. 2019. Gut microbial dataset of a foraging tribe from rural West Bengal - insights into unadulterated and transitional microbial abundance. Data in Brief 25: 103963. https://doi.org/10.1016/j.dib.2019.103963. 
Gao, X., M. Zhang, J. Xue, J. Huang, R. Zhuang, X. Zhou, H. Zhang, Q. Fu, and Y. Hao. 2018. Body mass index differences in the gut microbiota are gender specific. Frontiers in Microbiology 9: 1250. https:// doi.org/10.3389/fmicb.2018.01250.

Gaur, R., S.G. Sing, and M. Lakhanpal. 1999. Somatotypes of urban Meiteis of Imphal, Manipur. The Anthropologist 1 (4): 235-240. https://doi.org/10.1080/09720073.1999.11890605.

Gaur, R., and R.P. Singh. 1997. Age differences in somatotypes of Garhwali males 17-60 years of age. American Journal of Human Biology 9 (3): 285-290. https://doi.org/10.1002/(SICI)1520-6300(1997)9:3 $<285:$ :AID-AJHB1>3.0.CO;2-Y.

Genovese, J.E.C. 2009. Can body mass index (BMI) be used as a proxy for somatotype? The Social Science Journal 46 (2): 390-393. https://doi.org/10.1016/j.soscij.2009.04.007.

Ghosh, M., S. Bhandari, and K. Bose. 2018. Anthropometric characteristics and nutritional status of adult Sabars of Bankura District, West Bengal. Human Biology Review 7 (1): 71-83.

Ghosh, S., and S.L. Malik. 2010. Variations of body physique in Santhals: An Indian tribe. Collegium Antropologicum 34 (2): 467-472.

Guha, A. 2016. Should Lodhas become Hindus then? FORWARD Press. https://www.forwardpress.in/2016/ 07/lodhas-living-among-inhuman-indians/. Accessed 29 April 2020.

Heath, B.H., and J.E.L. Carter. 1967. A modified somatotype method. American Journal of Physical Anthropology 27: 57-74.

Hume, P.A., and T. Ackland. 2017. Physical and clinical assessment of nutrition status. In Nutrition is the prevention and treatment of disease, ed. A. Coulston, C. Boushey, M. Ferruzzi, and L. Delahanty, 4 ed., 71-84. Netherlands: Elsevier.

ISAK. 2011. International standards for anthropometric assessment. Lower Hutt: ISAK manual International Society for the Advancement of Kinanthropometry (ISAK).

Kalichman, L., G. Livshits, and E. Kobyliansky. 2004. Association between somatotypes and blood pressure in an adult Chuvasha population. Annals of Human Biology 31 (4): 466-476. https://doi.org/10.1080/03 014460412331281728 .

Kaur, G., S.P. Singh, and A.P. Singh. 2018. 2018. Trends in somatotype components of rural women of Punjab. Human Biology Review 7 (1): 84-93.

Kaur, H., and S.L. Malik. 2016. Magnitude of sex difference in body physique of Sainis of Punjab. Human Biology Review 5 (1): 72-85.

Koleva, M., A. Nacheva, and M. Boev. 2002. Somatotype and disease prevalence in adults. Reviews on Environmental Health 17 (1): 65-84. https://doi.org/10.1515/reveh.2002.17.1.65.

Kshatriya, G.K., and S.K. Acharya. 2016. Triple burden of obesity, undernutrition, and cardiovascular disease risk among Indian tribes. PLoS One 11 (1): e0147934. https://doi.org/10.1371/journal.pone.0147934.

Leonardo Mendonça, R.C., I. Sospedra, I. Sanchis, J. Mañes, and J.M. Soriano. 2012. Comparison of the somatotype, nutritional assessment and food intake among university sport and sedentary students. Medicina Clínica (Barcelona) 139 (2): 54-60. https://doi.org/10.1016/j.medcli.2011.03.034.

Longkumer, T. 2014. Physical activity and somatotype among Ao Naga boys. The Anthropologist 17 (2): 669-675.

Longkumer, T. 2016. Age and sex differences in human body physique and its association with nutrition: A cross-sectional study among the Ao children from Nagaland, North-East India. Indian Journal of Nutrition 3 (2): 132.

Mallick, A., A. Bhattacharya, and S.K. Roy. 2018. Spatial and temporal somatotype variation in Oraon tea garden and agricultural labourers of Alipurduar District, West Bengal. The Oriental Anthropologist 18 (2): 297-309. https://doi.org/10.1177/0976343020180208.

Menni, C., M.A. Jackson, T. Pallister, C.J. Steves, T.D. Spector, and A.M. Valdes. 2017. Gut microbiome diversity and high-fibre intake are related to lower long-term weight gain. International Journal of Obesity 41 (7): 1099-1105. https://doi.org/10.1038/ijo.2017.66.

Milton, K. 2000. Hunter-gatherer diets-A different perspective. The American Journal of Clinical Nutrition 71 (3): 665-667. https://doi.org/10.1093/ajcn/71.3.665.

Mukherjee, K., H. Harihar, P.N. Venugopal, A. Alam, and B. Rawat. 2015. Body mass index and chronic energy deficiency among adults of Tharu population, Uttarakhand, India. International Journal of Biomedical Research 6: 475-478.

Nandi, C. 2019. Development, 'unfulfilled' promises to decide fate of candidates in Tribal Bengal. Outlook. https://www.outlookindia.com/website/story/india-news-development-unfulfilled-promises-to-decide-fateof-candidates-in-tribal-bengal/329684. Accessed 29 Apr 2020.

Nemer, L., H. Gelband, and P. Jha. 2001. CMH working paper no WG5:11: Commission on macroeconomics and health. In The evidence base for interventions to reduce malnutrition in children under five and 
school-age children in low- and middle-income countries. Geneva, Switzerland: World Health Organization.

Onyango, A., K.G. Koski, and K.L. Tucker. 1998. Food diversity versus breastfeeding choice in determining anthropometric status in rural Kenyan toddlers. International Journal of Epidemiology 27 (3): 484-489. https://doi.org/10.1093/ije/27.3.484.

Organization WH. 1995. The use of interpretation of anthropometry - Report of WHO expert committee, WHO Tech Rep Series 854. Geneva: World Health Organization.

Organization WH. 2013. MDG1: Eradicate extreme poverty and hunger. Switzerland: World Health Organization.

Organization WH. 2020. WHO fact sheets for malnutrition. Switzerland: World Health Organization.

Penggalih, M.H.S.T., H.N. Nadia, F. Fajri, P. Diana, D.P.S. Maria, I.N.F. Winata, et al. 2016. Identification of somatotype, nutritional status, food and fluid intake in gymnastics youth athletes. Asia Pacific Journal of Clinical Nutrition 8: 1-8.

Press Trust of India. 2018. After 7 deaths, Bengal govt to provide nutritious food to Sabars, Lodhas. Business Standard. https://www.theweek.in/wire-updates/national/2018/12/05/cal6-wb-tribal-food.html. Accessed 29 Apr 2020.

Ramos-Jiménez, A., A. Wall-Medrano, R.P. Hernández-Torres, and M. Murguía-Romero. 2019. Somatotype and body image as predictors of overall and abdominal obesity in college students from northern Mexico. Revista Iberoamericana de Psicología del jercicio y el Deporte 14 (1): 2-7.

Roy, S.K., and T. Kundu Chowdhury. 2013. Differences in selected health traits between occupational groups among Oraons of Jalpaiguri district, West Bengal. Journal of Anthropology 7: 582036.

Sahani, R., R.K. Gautam, A.H. Golnabi, and N. Vedwan. 2018. Comparative study of chronic energy deficiency among adult males of Andaman and Nicobar islands and their counterparts. Anthropological Review 81 (1): 1-8. https://doi.org/10.2478/anre-2018-0001.

Shekar, M., J. Kakietek, J.D. Eberwein, and D. Walters. 2017. An investment framework for nutrition: Reaching the global targets for stunting, Anemia, breastfeeding, and wasting. Directions in development. Washington, DC: World Bank. https://doi.org/10.1596/978-1-4648-1010-7.

Sheldon, W.H., S.S. Stevens, and W.B. Tucker. 1940. The varieties of human physique. New York: Harper and Brothers.

Shimrah, C., S. Kaur, G. Kaur, and S. Chandel. 2020. Somatotype characteristics of Sunni Muslim population: A cross-sectional study. The Oriental Anthropologist 20 (1): 113-124. https://doi.org/10.1177/0972 558 X20913699.

Singal, P., and L.S. Sidhu. 1984. Age changes and comparison of somatotypes during 20 to 80 years in JatSikh and Bania females of Punjab (India). Anthropologischer Anzeiger 42 (4): 281-289.

Singal, P., L.S. Sidhu, and D.P. Bhatnagar. 1988. Estimated fat, bone mineral, total body water and cell solids in females of two communities of Punjab, India. Anthropologischer Anzeiger 46 (1): 51-57. https://doi.org/10.1127/anthranz/46/1988/51.

Singh, L.D. 2011. Somatotypes of the affluent and non-affluent Meitei boys of Manipur, India. The Anthropologist 3: 9-16.

Singh, R.K., H.W. Chang, D. Yan, K.M. Lee, D. Ucmak, K. Wong, M. Abrouk, B. Farahnik, M. Nakamura, T.H. Zhu, T. Bhutani, and W. Liao. 2017. Influence of diet on the gut microbiome and implications for human health. Journal of Translational Medicine 15 (1): 73. https://doi.org/10.1186/s12967-017-1175-y.

Srivastava, A., S.E. Mahmood, P.M. Srivastava, V.P. Shrotriya, and B. Kumar. 2012. Nutritional status of school-age children - A scenario of urban slums in India. Archives of Public Health 70 (1): 8. https://doi. org/10.1186/0778-7367-70-8.

St-Onge, M.P., and D. Gallagher. 2010. Body composition changes with aging: The cause or the result of alterations in metabolic rate and macronutrient oxidation? Nutrition 26 (2): 152-155. https://doi.org/10.101 6/j.nut.2009.07.004.

Turnbaugh, P.J., R.E. Ley, M.A. Mahowald, V. Magrini, E.R. Mardis, and J.I. Gordon. 2006. An obesity-associated gut microbiome with increased capacity for energy harvest. Nature 444 (7122): 1027-1031. https://doi.org/10.1038/nature05414.

Ulijaszek, S.J., and D.A. Kerr. 1999. Anthropometric measurement error and the assessment of nutritional status. The British Journal of Nutrition 82 (3): 165-177. https://doi.org/10.1017/S0007114599001348.

Urrutia-García, K., T. Martínez-Cervantes, O. Salas-Fraire, and N. Guevara-Neri. 2015. Somatotype of patients with type 2 diabetes in a university hospital in Mexico. Medicina Universitaria 17 (67): 71-74. https://doi.org/10.1016/j.rmu.2015.01.006.

Vyse, S.A. 1997. Believing in magic: The psychology of superstition. New York: Oxford University Press. 
Walker, A.W., J. Ince, S.H. Duncan, L.M. Webster, G. Holtrop, X. Ze, D. Brown, M.D. Stares, P. Scott, A. Bergerat, P. Louis, F. McIntosh, A.M. Johnstone, G.E. Lobley, J. Parkhill, and H.J. Flint. 2011. Dominant and diet-responsive groups of bacteria within the human colonic microbiota. The ISME Journal 5 (2): 220-230. https://doi.org/10.1038/ismej.2010.118.

Wan, Y., J. Yuan, J. Li, H. Li, K. Yin, F. Wang, et al. 2020. Overweight and underweight status are linked to specific gut microbiota and intestinal tricarboxylic acid cycle intermediates. Clinical Nutrition S02615614 (20): 30062-30065.

Williams, S.R., J. Goodfellow, B. Davies, W. Bell, I. McDowell, and E. Jones. 2000. Somatotype and angiographically determined atherosclerotic coronary artery disease in men. American Journal of Human Biology 12 (1): 128-138. https://doi.org/10.1002/(SICI)1520-6300(200001/02)12:1<128::AID-AJHB14>3.0. $\mathrm{CO} ; 2-\mathrm{X}$.

Wu, G.D., J. Chen, C. Hoffmann, K. Bittinger, Y.Y. Chen, S.A. Keilbaugh, M. Bewtra, D. Knights, W.A. Walters, R. Knight, R. Sinha, E. Gilroy, K. Gupta, R. Baldassano, L. Nessel, H. Li, F.D. Bushman, and J.D. Lewis. 2011. Linking long-term dietary patterns with gut microbial enterotypes. Science 334 (6052): 105-108. https://doi.org/10.1126/science.1208344.

\section{Comments}

Publisher's Note Springer Nature remains neutral with regard to jurisdictional claims in published maps and institutional affiliations. 